\title{
Electoral Accountability in the Midst of Criminal Violence: Evidence from Mexico
}

Sandra Ley

\begin{abstract}
Rising levels of crime and insecurity affect the quality of life. A fundamental question for the prospects of democracy is whether voters, in hopes of reaching better solutions to conditions of prevailing insecurity, can hold their elected officials accountable for such situations. This article argues that electoral accountability amid criminal violence requires voters to be able to assign responsibility for crime, and that partisan alignment across levels of government facilitates this task. Recent Mexican elections are examined to test this argument. Relying on both aggregate electoral data and individual survey evidence, this study shows that voters hold politicians accountable for crime in the narrow circumstances of organized crimerelated violence and political alignment. This evidence not only provides additional caveats to issue voting models, but also opens new avenues of research on electoral accountability.
\end{abstract}

C acing high levels of crime, can voters hold government accountable for its performance on security issues? This is not a minor or obvious question. Recent studies have found that while crime victimization stimulates nonelectoral forms of participation (Bateson 2012), voters living in crime-ridden environments tend to withdraw from the electoral arena and reduce their participation in elections (Bravo and Maldonado 2012; Carreras and Trelles 2012; Ley 2014). Therefore, when insecurity reaches a critical level, citizens are likely to be more concerned about their physical survival than electoral accountability.

At the same time, attributing responsibility for crime is not an easy task. When some political candidates or media seek to heighten the public's concern about security, incumbent party candidates may try to shift the blame for prevailing insecurity to other state and nonstate actors. Who is to blame? The national or the local governments? The police or criminal groups? Under these circumstances, the voter's process of attributing responsibility is quite complicated because the production of violence is dispersed among all these actors. The problem of accountability in the midst of violence is daunting.

This article argues that as organized criminal activity rises, voters hold their elected authorities accountable for their performance in controlling crime only when

Sandra Ley is an assistant professor of political studies at the Centro de Investigación y Docencia Económicas.sandra.ley@cide.edu 
their governing authorities are politically aligned. Attributing responsibility for prevailing insecurity in the midst of criminal competition is a complex process, and therefore voters hold their local authorities accountable only when the same party controls each of the relevant levels of governance. Evidence shows that voters facing rising insecurity in politically aligned regions are better able to incorporate insecurity evaluations into their voting decisions.

Drawing from the Mexican experience, this study explores how government's performance in handling insecurity shapes voting behavior. Specifically, it seeks to understand whether voters are able to hold governments accountable for prevailing violence, as well as the extent to which security concerns play an important role in voting decisions. For this purpose, the study combines aggregate electoral data and individual survey evidence. It uses electoral information from local races during the second half of President Felipe Calderón's administration (2009-12), as well as from the 2012 presidential election. In order to examine the logic of vote choice at the individual level, the study also uses data from the 2012 Comparative Study of Electoral Systems (CSES) (See BIIACS 2012).

This article first examines the literature on crime issue voting and responsibility attribution. Given that the focus is on criminal violence, the article also discusses the logic of organized crime and its role in vote choice, and then presents the main hypotheses. The issue of crime in recent Mexican elections is explored in order to understand its role in voting behavior. Finally, the article presents empirical evidence on how security performance shapes voting behavior in both municipal and presidential elections. Overall, the results show that voters hold politicians accountable for crime in the narrow circumstances of organized crime-related violence and political alignment. In the context of the drug war in Mexico, electoral punishment against the national incumbent party was magnified by its campaign emphasis on the issue of crime in a context where it was unable to effectively control violence.

\section{Crime Issue Voting}

The tangible consequences of increasing crime rates make security a salient and accessible issue in voters' minds. Crime and violence have been shown to have immediate effects on economic development, as well as on human and social capital (Prillaman 2003; Robles et al. 2013; Caudillo and Torche 2014). Just like unemployment and inflation, insecurity and crime affect quality of life. Under such circumstances, the electorate's concern about crime rises and is likely to play a role in voting decisions.

Even if the incidence of crime does not actually result in a major security crisis, media and political discourse can still heighten the public's concern about security. The media tend to saturate viewers with coverage of crime news and sensationalize the issue (Romer et al. 2003). Crime and security are also issues that political candidates, particularly those from right-wing parties, tend to emphasize in their campaigns (Marion and Farmer 2003; Smith 2010). In general, such exposure primes voters' concerns about insecurity (Beckett 1997; Altheide 2002) and may even affect their support for "iron fist" policies (Krause 2014). 
Overall, the tangible consequences that criminal violence has for quality of life, as well as the strategic use of the topic of crime by politicians and the media alike, make security a relevant noneconomic issue on which voters may base their electoral decisions. In fact, across different contexts, previous literature has found that crime and violence play a role in vote choice. In the United States, crime has been found to influence local elections (Cummins 2009). Violent crimes in particular appear to have the most negative impact on U.S. governors' electoral fortunes. Similarly, U.S. House members' voting records regarding crime policy influence their vote shares (Canes-Wrone et al. 2011). Research in comparative politics has also shown that in elections that occur in the midst of crises of insecurity, involving human rights violations or political violence, voters shift their attention toward such issues and hold their national governments accountable accordingly (Singer 2011; Holmes and Gutiérrez de Piñeres 2012). Furthermore, perceptions of insecurity and fear of crime are significant predictors of support for opposition presidential candidates in Latin America (Pérez 2015).

While the literature on crime issue voting delivers good news for electoral accountability, it has largely dismissed the process of responsibility attribution. Studies that have examined the role of crime in electoral choice have been guided mainly by a retrospective voting model, whereby local and national incumbent governments are evaluated on the basis of their own performance regarding crime and voters punish or reward them accordingly. However, before sanctioning, voters need to decide on the extent to which incumbents are in fact responsible for rising or declining levels of crime.

How do voters attribute responsibility for an issue in which several government authorities intervene? By supporting or disapproving punitive policies, legislators have a role in the evolution of crime (Canes-Wrone et al. 2011). Subnational executives can also influence violence trends through their crime spending or punishment policies (Simon 2006). Although national politicians cannot directly prosecute criminals, they have an even wider political capacity to frame political issues in terms of public insecurity and outrage about crime (Marion and Farmer 2003; Simon 2006; Smith 2010). Furthermore, incumbent party candidates may try to shift the blame for prevailing insecurity to other actors, ranging from the military, the police, or other government authorities to criminal groups.

Under these circumstances, voters' process of responsibility attribution becomes quite complex because the production of violence is dispersed among several actors, and because cognitive abilities vary from person to person (Javeline 2003). In this regard, research has shown that electoral behavior is conditioned on whether voters are able to assign blame (Arceneaux 2003). If the level of government to be elected is not considered responsible for a given problem, voters' ability to hold authorities accountable for rising violence diminishes. The problem of accountability in the midst of violence pushes us to analyze how the process of responsibility attribution for crime and insecurity can take place.

The prevailing literature on crime issue voting has also failed to distinguish between the types of violence or the sources of criminal activity. Crime in the Latin 
American region, unlike that in Western Europe or the United States, is not generated by small and diffuse crime groups outside state institutions. Instead, it is largely produced by violent organized criminal groups that operate in collusion with government authorities from across the ideological spectrum (Snyder and DuránMartínez 2009). This characteristic gives organized crime-related violence a unique character. While petty crime may be the result of social and economic circumstances for which governments do not necessarily have a direct responsibility (Sampson 1985), organized crime-related violence is closely linked to government authorities' political decisions (Trejo and Ley 2016) and their cooperation with such groups (Arias 2006; Felbab 2010).

This discussion indicates that two issues need to be resolved here. On the one hand, it is necessary to understand the shortcuts voters may use to attribute responsibility for crime. On the other, it is important to identify and distinguish the role of organized criminal violence in electoral choice, in contrast with other types of crime.

\section{AtTRibuting Responsibility FOR CRIME AND INSECURITY}

Information is crucial for voters' decisionmaking process. However, getting informed is costly and difficult (Berinsky 2005), particularly when various parties provide different and opposing explanations for the same issue and even blame one another. There is wide evidence that in such situations, voters' ability to make causal associations and attribute responsibility is limited (Norpoth 2001; Javeline 2003; Gélineau and Remmer 2006).

The political context in which elections take place helps to simplify or complicate voters' reward-punishment calculus (Powell and Whitten 1993; Hobolt et al. 2013). When the institutional and governmental structures blur lines of responsibility, it is quite difficult for voters to distinguish which part or level of government is responsible for different policy outcomes, and therefore hard to reward or punish accordingly. Institutional factors, such as federalism, bicameralism, or the legislative committee structure, disperse responsibility across many political actors. Likewise, the degree of government cohesion, either through single-party government or dominance of the main governing party, helps voters identify a target they can reward or punish.

Government cohesion can actually convey a lot of information to voters, not only in terms of a party's policy preferences but also about its successes and failures (Leyden and Borrelli 1995, Rudolph 2003). As proposed by the responsible party model, when one single party controls different branches or levels of government, citizens administer sanctions more easily (Leyden and Borelli 1995). Under unified government, voters are better able to determine which party is worthy of blame or reward. Empirical evidence has in fact shown that instead of trying to identify which part of the political system is responsible, voters tend to focus on identifying a single political party that they can reward or punish (Hobolt et al. 2013). Therefore, the 
cohesion of the incumbent government, across both levels and branches, is even more important than the institutional dispersion of power for responsibility attribution.

Using partisanship as a "cognitive shortcut" to assign responsibility and vote accordingly may be even more necessary for the evaluation of an issue such as crime, in which not only different levels of government intervene, but law enforcement and military authorities, as well as nonstate actors, also deeply affect trends in violence and perceptions of security through policing and repression (Uang 2013). The complexity of the issue of crime therefore requires voters to find ways to attribute responsibility in this case.

\section{The Logic of Organized Crime}

Organized crime groups (OCGs) are informal business enterprises that regulate and control the production and distribution of illicit services or products (Varese 2010). As Hagan (1983) argues, in order to carry out these activities, organized crime needs an internal and operational structure that is quite different from that of "nonorganized crime groups" or petty criminals. To operate, organized crime requires a highly controlled structure in terms of hierarchy, membership, and secrecy. Most important is that unlike other groups, the existence and survival of organized crime depends on violence and corruption.

Violence in illegally organized criminal markets is often deployed strategically to gain market share or solve contractual problems (Andreas and Wallman 2009). Such violence varies in terms of frequency and visibility, but overall, organized crime-related violence tends to exhibit higher levels of cruelty and brutality than ordinary crime (Durán-Martínez 2015).

When and where OCGs settle, as well as whether they use violence or not, depends to a great extent on the availability of informal local networks of government protection (Snyder and Durán-Martínez 2009). In general, OCGs make use of plata o plomo (silver or lead) offers to buy protection for their territories and impunity for their crimes. In return, public officials refrain from enforcing the law or enforce it selectively. Multiple accounts from across the world have demonstrated this criminal-political nexus (Arias 2006; Chin and Godson 2006; Felbab 2010).

The nature of organized crime-related violence and the characteristic collusion between government authorities and organized criminal groups-either voluntary or not-gives organized crime a different character. Most important for our purposes, unlike "ordinary" intentional homicides that may be related to interpersonal conflicts, organized crime-related deaths reveal not only some degree of government corruption but also the inability of government to fulfill one of its basic functions. Therefore, organized crime-related violence is likely to draw even more public attention and social concern. It may also make voters take a closer look at their government's performance and actions. The pending issue is whether voters actually hold authorities accountable for organized crime-related violence. 


\section{HYPOTHESES}

Drawing from this theoretical framework, this study assesses two alternative arguments: the crime issue voting and the responsible party hypotheses. In addition, given the unique character that organized crime arguably has, the study focuses on organized crime-related violence. The crime issue voting argument would expect that

H1. Electoral support for incumbent party candidates varies inversely with local organized crime-related violence, regardless of their partisan alignment.

In contrast, the responsible party model would propose that

H2. Electoral support for in-party candidates varies inversely with local organized crime-related violence only when partisanship is shared across government authorities.

Note that while in $\mathrm{H} 1$ voters hold their authorities accountable for their corresponding responsibilities, in $\mathrm{H} 2$ the fate of candidates is shaped by their partisan affiliation and alignment across levels of government.

The following sections explore the extent to which Mexican elected officials have been held accountable for their performance in controlling criminal violence.

\section{INSECURITY, CAMPAIGNS, ANd Elections in MeXico}

This study tests the two hypotheses on the Mexican case for both theoretical and methodological reasons. Specifically, it examines electoral outcomes and electoral behavior during Calderón's administration (2006-12), when levels of violence experienced an exponential growth.

Just a few days after being sworn into office, the Mexican president declared a war against drugs and began a militarized strategy to fight crime. Violence quickly began to rise. By the end of his administration, more than 70,000 people had been killed (Molzahn et al. 2013), and more than 22,000 disappeared (Data Cívica 2015). Also, more than 200 public officials and party members were targets of lethal attacks by OCGs (Trejo and Ley 2015).

During the 2009 midterm election, the national incumbent party, Calderón's PAN, emphasized the president's willingness to fight crime as no party had done before and blamed opposition parties for the prevailing violence. ${ }^{1}$ Thus the PAN began to "own" the issue of crime and used it as an asset to persuade voters to vote for its candidates. Therefore, the Mexican case allows us to understand whether issue ownership on crime benefited or harmed the PAN's electoral support.

It is interesting that despite the alarming levels of violence, crime and insecurity were barely discussed in the 2012 presidential campaigns (Putnam 2013). None of the four candidates in that election made the issue of violence a prominent one. ${ }^{2}$ Security strategies and policies to deal with violence were vaguely defined by all four candidates. However, crime and insecurity were topics present in the majority of 
Calderón's speeches (Norzagaray López 2010; Bravo Regidor 2011), as well as in local elections (Langston and Ley 2016).

During local campaigns, members and candidates of the president's party repeatedly emphasized the "get tough on criminals" approach (Reforma 2009; Beltrán 2010; Hernández and Salazar 2010; Minjares 2010; L. García 2011). PAN candidates tended to emphasize their support for the president's policies on security. For example, the PAN candidate for mayor in Altamira, Tamaulipas, José Luis Vargas, proposed to work closelywith Calderón, arguing that "with his help, we will be able to fight one of the electorate's main concerns" (quoted in Azuara 2010). Similarly, the PAN candidate for mayor in Culiacán, Sinaloa, proposed the implementation of a security strategy similar to what Calderón had done in Ciudad Juárez (Beltrán 2010). This study seeks to understand whether, by aligning themselves with the federal security policy, PAN incumbents and candidates made insecurity prominent in voters' minds and made the federal strategy against organized crime an issue on which to evaluate the incumbent national party.

At the same time, non-PAN members emphasized the lack of results from the president's militarized strategy. This was most evident in the case of Tamaulipas, where local elections in 2010 were clouded by the assassination of PRI gubernatorial candidate Rodolfo Torre Cantú. Immediately, the PRI asserted that this was the response of organized crime to the federal government's declaration of war (Álvarez 2010; Romero 2010). This kind of statement is likely to raise the awareness of the national security policy and polarize the electorate's views.

It is important to consider that this partisan confrontation regarding the issue of crime took place in one of the most disciplined party systems in Latin America (Nacif 2002) and in a country where presidential re-election is forbidden and, up until 2014, the re-election of mayors was not permitted either. These characteristics of the Mexican party and electoral systems shift voters' attention toward the evaluation of parties instead of candidates as individuals with their own faults and merits.

As much as Mexican parties tried to simplify the issue of crime, discerning who was responsible for prevailing insecurity was not an easy task for voters. Although violence may be initially triggered by OCG competition, organized crime cannot operate without the "cooperation" of some government officials and law enforcement. In Mexico, this problem is magnified by its multiple state forces-federal, state, and municipal - that operate at the local level, along with a massive military deployment that also conducts policing operations across municipalities with high criminal activity. Together, they have generated violent processes that also directly and indirectly have increased and radicalized criminal violence (Sabet 2012). Despite the federal government's insistence on blaming municipal police forces for rising crime, the local policing scheme involving the military further blurs the lines of responsibility for crime and insecurity.

Consequently, the potential responsible agents are numerous: OCGs, the military, federal police, local police, the president, governors, and mayors. The process of responsibility attribution is quite complex because the production of violence is dispersed among all these actors. 
Table 1. Responsibility Attribution for the Security Situation in Mexico, 2012 (percent)

\begin{tabular}{lc}
\hline \hline Political Actor & Response Percentage \\
\hline Government authorities & 45 \\
Organized crime & 20 \\
All (spontaneous) & 13 \\
Army & 8 \\
Federal police & 8 \\
Local police & 5 \\
None/Other (spontaneous) & 1 \\
\hline \hline
\end{tabular}

Source: Ley and Dorff 2012.

As table 1 shows, survey data reveal that 45 percent of Mexicans attributed responsibility to government authorities, broadly defined, while 20 percent attributed responsibility to organized crime. ${ }^{3}$ Out of the group of respondents who considered the government responsible for the security situation, 71 percent identified Calderón as the main responsible agent. This article seeks to explain whether such a view translated into an effective process of electoral accountability, either to reward or to punish the incumbent party.

Taken together, the circumstances surrounding elections during the Calderón administration-PAN local candidates' emphasis on the federal military strategy, non-PAN candidates' blaming the president's war on drugs, the relative absence of crime as a presidential campaign theme, and the complex process of responsibility attribution-make the Mexican case particularly relevant in exploring the issue of electoral accountability in the midst of violence.

\section{DAta AND Methods}

To accurately assess and differentiate the impact of criminal violence on electoral accountability, it is necessary to conduct a comparative test of elections at both the local and federal levels, as well as at both the aggregate and individual levels of analysis. Aggregate electoral data allow us to examine how violence may have affected electoral preferences across elections in different municipalities. Survey data help us to accurately evaluate the behavioral consequences of criminal violence at the individual level, avoiding ecological fallacies. 


\section{Aggregate Level}

Aggregate data in local elections in Mexico are analyzed first. Given that Calderón began the militarized strategy against organized crime in 2006 and that violence began to reach its highest levels by 2009, this study relies on the mayoral elections that occurred during the second half of the Calderón administration, 2009-12. ${ }^{4}$ Next the relationship between violence and electoral preferences in the 2012 presidential election is tested, also at the municipal level.

The dependent variable at the aggregate level is measured in two ways. For both local and presidential elections, I calculate the vote share of the national incumbent party (PAN). In addition, for mayoral elections, I use the local incumbent party's vote share. These measures are derived from the electoral statistics collected by the state electoral institutes and the national electoral authority (Instituto Nacional Electoral, INE).

To analyze the impact of violence on aggregate electoral support, I rely on three measures. First, I use the national census (INEGI) dataset on homicides, which is derived from death certificates. However, these data do not focus exclusively on organized crime-related homicides, which, I argue, are most relevant for voting decisions in a context of criminal violence. Although the federal government initially released a dataset on "homicides presumably related to organized crime," this information was made available only for 2007-10. Because this dataset cannot be used for the entire period under study, two alternative sources are used.

One is the Criminal Violence in Mexico (CVM) Dataset, an original newspaper-based databank collected by Trejo and Ley (2016). This database collects information on organized crime-related violence during the 1995-2012 period. ${ }^{5}$ The other is the Criminal Aggression against Political Actors in Mexico (CAPAM) Dataset by Trejo and Ley (2015), which collects information on lethal and nonlethal attacks perpetrated by organized crime against government authorities, political candidates, and party activists from 1995 to 2012.

Relying on both the INEGI and CVM data, I calculate the total number of deaths to compute the Homicide rate per thousand inhabitants during the year preceding the election. ${ }^{6} \mathrm{~A}$ third measure, based on the CAPAM Dataset, includes the count of the number of violent acts perpetrated by OCGs against Mexican authorities and party members during the course of the electoral campaign. Drawing from Sberna 2011, I refer to this measure as Criminal-electoral violence; that is, any organized act or threat by criminal organizations that occurs during an electoral process, from the date of nomination for political offices to the date of elections, to intimidate, physically harm, blackmail, or abuse a political stakeholder. In addition, given the detailed information from which the CAPAM Dataset is derived, I also include the number of aggressions directed exclusively against PAN members.

Since this study argues that the impact of violence on the level of electoral support for candidates of the national in-party at the subnational level is conditional on the local incumbent's shared partisanship, I also incorporate a dichotomous variable to identify PAN incumbent governments. 
To account for economic voting, measures on unemployment and GDP percent change are included. ${ }^{7}$ I also control for the incumbent party's previous vote share. ${ }^{8}$ Sociodemographic control variables include logged population size, level of urbanization, and poverty.

For the analysis of both municipal and federal elections, given the nature of the aggregate-level dependent variable, a simple ordinary least squares regression with clustered standard errors is estimated.

\section{Individual Level}

Survey data are also used to analyze the role of criminal violence in the individual voting decision. This analysis relied on the postelectoral survey of the 2012 Mexican Comparative Study of Electoral Systems (CSES). This was a national representative survey with a sample of 2,400 adults aged 18 and older. ${ }^{9}$ It was conducted two weeks after the July 1 federal election (July 13-19).

According to this survey, 43 percent of respondents reported voting for the PRI, 24 percent for the PRD, and 22 percent for the PAN. These numbers do not deviate significantly from the official electoral results, which showed that Enrique Peña Nieto (PRI) won with 39 percent of the vote, followed by Andrés Manuel López Obrador (PRD) with 32 percent and PAN candidate Josefina Vázquez Mota with 26 percent. Therefore, CSES is a reliable data source to explore the linkage between individual perceptions of government performance and electoral choice.

The dependent variable at the individual level of analysis is the reported vote choice in the 2012 presidential election. It is coded as a dichotomous measure equal to 1 if the respondent reported voting for the candidate or party of the president.

To examine how the importance an individual attaches to crime and insecurity affects electoral accountability, the analysis included evaluations of national security and victimization experiences. ${ }^{10}$ To test the contextual effect of violence on vote choice, each respondent was matched with the corresponding data on his or her particular context of violence, at the municipal level. ${ }^{11}$ Given the argument on the conditional effect of crime on vote choice, I also matched information on the partisanship of the respondent's incumbent mayor. Specifically, I identified PAN and non-PAN municipal presidents.

A control of responsibility attribution is included to assess whether only voters who attribute responsibility for prevailing violence to the federal government actually hold the president and the president's party accountable on the issue. Considering that media exposure tends to prime voters' concern about insecurity, the analysis also included questions on television consumption, which has been shown to have the most impact on crime perception (Beckett 1997; Altheide 2002; Krause 2014). In addition, all models include the following control variables: evaluations of the national economy, presidential approval, party identification, education level, age, and gender.

Given the dichotomous nature of the dependent variable and the objective of examining the contextual effect of violence on the individual's vote choice, I esti- 
mate multilevel logistic regressions, with individuals modeled at level 1 , nested within municipalities. I use the municipality as the level 2 unit because this is a better measure of the context in which voting takes place. The disaggregation at the municipal level allows for greater levels of variation for statistical analysis and is also a more accurate depiction of the voter's decision process. After the neighborhood, the municipality is the most immediate political and social milieu that shapes the way Mexican citizens view politics. The municipality is also the administrative area closest to Mexican citizens, and it is therefore the closest area of action and the unit from which to assess the impact of violence on political behavior.

\section{RESULTS}

\section{Aggregate Level}

Table 2 reports the results for two different specifications of the basic model of mayoral elections. Models 1 and 2 use the PAN's vote share as the dependent variable. Two findings stand out here. First, the level of electoral support for candidates of the national in-party (PAN) at the subnational level varies inversely only with the local level of organized crime-related violence, as measured by the CVM Dataset. As expected, violence that is not exclusively related to organized crime, as measured by census data (INEGI), does not have a statistically significant effect on the PAN's electoral support. Overall, I find that each unit increase in the yearly homicide rate resulting from OCG activity translates into a 1.76 percentage point decrease in the PAN's vote share in mayoral elections. Therefore, in municipalities with the highest homicide rates (12 per 1,000 inhabitants), the PAN exhibits, on average, vote shares that are 20 percentage points lower than in municipalities with no incidence of drug-related violence.

Second, lethal attacks directed against politicians have an even larger negative effect on voters' support for the national incumbent party's candidates than the homicide rate. For every violent event perpetrated against political actors over the course of the electoral process in a given municipality, the PAN's vote share decreases by 3.6 percentage points.

Models 3 and 4 use the vote share for the incumbent mayor's party as the dependent variable. To examine whether violence has a differentiated impact in municipalities ruled by PAN mayors, violence-related variables are interacted with the mayors' party identification. Models 3 and 4 reveal that when using a general measure of local incumbent support, criminal violence measured through the homicide rate has no impact, regardless of the incumbent's party identification. ${ }^{12}$

The fact that organized crime-related homicides are negatively associated with the PAN's vote share (models 1 and 2) but not with the overall incumbent vote share (models 3 and 4), indicates that only the national incumbent party was held accountable for security. As noted earlier, local elections revealed a deep division between PAN and non-PAN candidates. While the former emphasized the issue of insecurity and praised the federal strategy against organized crime, the latter blamed 
Table 2. Electoral Support and Violence in Local Elections, 2009-2012

\begin{tabular}{|c|c|c|c|c|}
\hline & \multicolumn{2}{|c|}{$\begin{array}{c}\text { DV: } \\
\text { PAN Vote Share }\end{array}$} & \multicolumn{2}{|c|}{$\begin{array}{c}\text { DV: } \\
\text { Incumbent Vote Share }\end{array}$} \\
\hline & Model 1 & Model 2 & Model 3 & Model 4 \\
\hline Homicide rate, CVM & $\begin{array}{l}-1.760^{* * *} \\
{[0.551]}\end{array}$ & & $\begin{array}{c}-0.105 \\
{[0.805]}\end{array}$ & \\
\hline $\mathrm{CVM}^{*} \mathrm{PAN}$ mayor & & & $\begin{array}{c}0.235 \\
{[0.561]}\end{array}$ & \\
\hline Homicide rate, INEGI & & $\begin{array}{c}-0.512 \\
{[0.697]}\end{array}$ & & $\begin{array}{c}0.324 \\
{[0.382]}\end{array}$ \\
\hline INEGI*PAN mayor & & & & $\begin{array}{c}-0.163 \\
{[1.433]}\end{array}$ \\
\hline Criminal-electoral violence & $\begin{array}{l}-3.607^{* *} \\
{[1.321]}\end{array}$ & $\begin{array}{l}-3.758^{* * *} \\
{[1.288]}\end{array}$ & $\begin{array}{l}2.967^{* * *} \\
{[0.716]}\end{array}$ & $\begin{array}{l}2.855^{* * *} \\
{[0.683]}\end{array}$ \\
\hline C-E violence*PAN mayor & & & $\begin{array}{l}-7.117^{* * *} \\
{[2.437]}\end{array}$ & $\begin{array}{l}-7.041^{* * *} \\
{[2.423]}\end{array}$ \\
\hline PAN mayor dummy & $\begin{array}{l}-1.207 \\
{[2.972]}\end{array}$ & $\begin{array}{l}-1.204 \\
{[2.973]}\end{array}$ & $\begin{array}{r}-2.101^{*} \\
{[1.106]}\end{array}$ & $\begin{array}{r}-2.048^{*} \\
{[1.197]}\end{array}$ \\
\hline PAN governor dummy & $\begin{array}{l}-3.638 \\
{[3.994]}\end{array}$ & $\begin{array}{l}-3.497 \\
{[4.020]}\end{array}$ & $\begin{array}{l}-4.161^{* *} \\
{[1.625]}\end{array}$ & $\begin{array}{l}-4.152^{* *} \\
{[1.622]}\end{array}$ \\
\hline Unemployment, \% change & $\begin{array}{r}-0.172^{*} \\
{[0.096]}\end{array}$ & $\begin{array}{r}-0.178^{*} \\
{[0.096]}\end{array}$ & $\begin{array}{c}0.008 \\
{[0.061]}\end{array}$ & $\begin{array}{l}0.01 \\
{[0.061]}\end{array}$ \\
\hline GDP, $\%$ change & $\begin{array}{l}0.72 \\
{[0.661]}\end{array}$ & $\begin{array}{c}0.705 \\
{[0.671]}\end{array}$ & $\begin{array}{l}0.630^{* * *} \\
{[0.203]}\end{array}$ & $\begin{array}{l}0.639^{* * *} \\
{[0.206]}\end{array}$ \\
\hline Previous PAN vote & $\begin{array}{l}0.468^{* * *} \\
{[0.118]}\end{array}$ & $\begin{array}{l}0.468^{* * *} \\
{[0.118]}\end{array}$ & & \\
\hline Previous incumbent vote & & & $\begin{array}{l}0.630^{* * *} \\
{[0.044]}\end{array}$ & $\begin{array}{l}0.628^{* * *} \\
{[0.044]}\end{array}$ \\
\hline Concurrent elections & $\begin{array}{c}0.641 \\
{[4.470]}\end{array}$ & $\begin{array}{c}0.665 \\
{[4.498]}\end{array}$ & $\begin{array}{l}-2.101 \\
{[2.388]}\end{array}$ & $\begin{array}{l}-2.036 \\
{[2.419]}\end{array}$ \\
\hline Population log. & $\begin{array}{l}-0.627 \\
{[0.699]}\end{array}$ & $\begin{array}{l}-0.581 \\
{[0.702]}\end{array}$ & $\begin{array}{c}-0.156 \\
{[0.355]}\end{array}$ & $\begin{array}{l}-0.139 \\
{[0.349]}\end{array}$ \\
\hline$\%$ Urban & $\begin{array}{c}-0.208^{*} \\
{[0.121]}\end{array}$ & $\begin{array}{c}-0.208^{*} \\
{[0.121]}\end{array}$ & $\begin{array}{l}-0.191^{* *} \\
{[0.075]}\end{array}$ & $\begin{array}{l}-0.189^{* *} \\
{[0.077]}\end{array}$ \\
\hline Poverty & $\begin{array}{c}-0.248^{*} \\
{[0.145]}\end{array}$ & $\begin{array}{l}-0.243 \\
{[0.145]}\end{array}$ & $\begin{array}{c}-0.103^{* *} \\
{[0.049]}\end{array}$ & $\begin{array}{r}-0.100^{*} \\
{[0.050]}\end{array}$ \\
\hline Constant & $\begin{array}{l}65.404^{* *} \\
{[24.475]}\end{array}$ & $\begin{array}{l}64.879^{* *} \\
{[24.372]}\end{array}$ & $\begin{array}{l}44.516^{* * *} \\
{[10.338]}\end{array}$ & $\begin{array}{l}44.217^{* * *} \\
{[10.461]}\end{array}$ \\
\hline Observations & 1,993 & 1,993 & 1,986 & 1,986 \\
\hline R-squared & 0.305 & 0.303 & 0.301 & 0.301 \\
\hline
\end{tabular}

Clustered standard errors in brackets.

${ }^{* * *} \mathrm{p}<0.01,{ }^{* *} \mathrm{p}<0.05,{ }^{*} \mathrm{p}<0.10$ 
the federal government for the continued spread of violence across the country. This finding suggests that by "owning" the issue of crime while at the same time being unable to effectively control violence-as measured by higher levels of organized crime-related homicides-PAN candidates' campaign strategy was ultimately harmful to their party. Voters punished the national incumbent party for the lack of results on an issue the PAN claimed to be working hard on.

Models 3 and 4 further show that criminal-electoral violence has a statistically significant impact on subnational incumbents' electoral support. Moreover, criminalelectoral violence does have a differentiated effect according to the party identification of the municipal incumbent government. The count of aggressive acts against politicians has a positive coefficient, which indicates that criminal attacks have a positive impact on the vote share of the local incumbent party only when the PAN is not in office (2.9 percent increase per event). The negative coefficient for PAN mayors implies that overall, even in the absence of criminal-electoral violence, PAN candidates in PAN-ruled municipalities performed significantly worse in local elections than their non-PAN counterparts. The interaction term indicates that rising levels of criminal-electoral violence under a PAN incumbent translate into considerably lower vote shares for his or her party (7 percent decrease per violent event).

The latter finding supports the hypothesis that the level of electoral support for candidates of the national in-party at the subnational level varies inversely with the level of criminal violence at the local level only when subnational authorities share the president's partisanship (H2). Consistent with the responsible party hypothesis, voters appear to use partisanship as a shortcut to attribute responsibility for crime and insecurity. The results further confirm that it is organized crime-related violence that has the most impact on electoral choice. In particular, criminal-electoral violence has the largest effect. Why?

For the purposes of this statistical analysis, I count only the number of criminal attacks against public figures that occurred during the campaign period. ${ }^{13}$ However, it is important to note that more than two hundred Mexican public officials (across different levels of government) and party members were targets of lethal attacks by OCGs during the entire Calderón administration (Trejo and Ley 2015). Given the public and targeted nature of criminal-electoral violence, it receives great media attention and therefore plays a greater role in voters' electoral decisions. It is during these events that criminal violence becomes more noticeable because the victim is known and the level of cruelty and brutality becomes evident. Criminal-electoral violence further reveals the vulnerability that even highly visible public authorities face in a context of intense criminal competition.

The subsequent question is why only PAN candidates were negatively affected by this type of violence, particularly in PAN-led municipalities. It is most likely that the prominence of this kind of violent events draws attention to the issue of insecurity on which mainly PAN candidates campaigned (Langston and Ley 2016), putting the PAN's performance in question. Attacks against politicians are perceived by the public as an inability to reduce violence, particularly by the party that claimed to be fighting organized crime. 
Furthermore, these are events that polarize partisan positions on crime. The assassination of the PRI's gubernatorial candidate in Tamaulipas was used by the opposition to delegitimate the federal government's war on drugs. Both the PRI and the PRD claimed that the lack of security and violent attacks against their candidates and public officials - from Baja California to Michoacán-was the federal government's responsibility and the result of its failed strategy against organized crime (Martínez 2009; Romero 2010; A. García 2011; Luján 2011). In a PAN municipality, such partisan positions are likely to be further polarized and more evident to voters-given the partisan alignment with the federal government-ultimately affecting their perceptions about crime and corresponding electoral preferences.

The next step is to examine the role of criminal violence in the 2012 Mexican presidential election, which lacked major discussion of the issue of rising crime and violence. Therefore, this is an even more critical test for the crime issue voting hypothesis.

Table 3 shows that contrary to the previous set of findings, neither ordinary homicides nor organized crime-related violence had a statistically significant effect on the PAN's vote share in the presidential election. ${ }^{14}$ Unlike its effect in subnational elections, shared partisanship across levels of government did not help voters attribute responsibility for crime.

There are three possible explanations for these results. One is that criminal violence only has an effect on the PAN's electoral performance when directed against its members, and voters' preferences were affected to the detriment of that party. Models 3 and 4 introduce a measure of the number of acts of aggression directed only against PAN politicians, either candidates or elected public officials. Results indicate that for every violent event by organized crime against Panistas, the PAN's vote share decreased by 3 percentage points $(\mathrm{p}<0.10) .{ }^{15}$

Yet another possibility is that voters simply did not hold the national government accountable for the local situation of insecurity in the presidential election. After all, this was not a major topic in the presidential campaign. In addition, many other agents at the local level were to blame, and voters may have had moredetailed information about local politics. Furthermore, it is important to consider that perceptions of violence do not always match with objective conditions of insecurity (Villarreal and Silva 2006). Therefore we also need to examine the role individual perceptions of crime and insecurity played in shaping electoral preferences in the 2012 election.

\section{Individual Level}

The results of the multilevel analysis of vote choice in the 2012 Mexican presidential election are presented in table $4 .{ }^{16}$ Consistent with the aggregate-level evidence on the 2012 federal election, survey data show that individual voting preferences were unaffected by contextual violence, as measured by the homicide rate. Although previous models of the 2012 presidential election revealed that only violence specifically directed against PAN members was associated with diminished voter support for that party, I am unable to include such a measure in this individual-level analy- 
Table 3. Electoral Support and Violence in the 2012 Mexican Presidential Election

\begin{tabular}{|c|c|c|c|c|}
\hline & Model 1 & Model 2 & Model 3 & Model 4 \\
\hline Homicide rate, CVM & $\begin{array}{c}0.294 \\
{[0.427]}\end{array}$ & & $\begin{array}{c}0.356 \\
{[0.410]}\end{array}$ & \\
\hline $\mathrm{CVM}^{*} \mathrm{PAN}$ mayor & $\begin{array}{c}0.911 \\
{[0.950]}\end{array}$ & & & \\
\hline Homicide rate, INEGI & & $\begin{array}{c}0.057 \\
{[0.471]}\end{array}$ & & $\begin{array}{c}-0.066 \\
{[0.544]}\end{array}$ \\
\hline INEGI*PAN mayor & & $\begin{array}{c}-1.105 \\
{[1.130]}\end{array}$ & & \\
\hline Criminal-electoral violence & $\begin{array}{c}-0.434 \\
{[0.684]}\end{array}$ & $\begin{array}{c}-0.396 \\
{[0.686]}\end{array}$ & & \\
\hline C-E violence*PAN mayor & $\begin{array}{l}1.05 \\
{[1.569]}\end{array}$ & $\begin{array}{c}1.176 \\
{[1.509]}\end{array}$ & & \\
\hline Violence vs. PAN members & & & $\begin{array}{r}-3.302^{*} \\
{[1.641]}\end{array}$ & $\begin{array}{r}-3.277^{*} \\
{[1.625]}\end{array}$ \\
\hline PAN mayor dummy & $\begin{array}{c}2.027^{* *} \\
{[0.934]}\end{array}$ & $\begin{array}{c}2.267^{* *} \\
{[1.058]}\end{array}$ & $\begin{array}{c}2.105^{* *} \\
{[0.925]}\end{array}$ & $\begin{array}{c}2.095^{* *} \\
{[0.918]}\end{array}$ \\
\hline PAN governor dummy & $\begin{array}{c}-0.877 \\
{[1.780]}\end{array}$ & $\begin{array}{l}-0.911 \\
{[1.783]}\end{array}$ & $\begin{array}{c}-0.876 \\
{[1.774]}\end{array}$ & $\begin{array}{l}-0.91 \\
{[1.786]}\end{array}$ \\
\hline Unemployment, \% change & $\begin{array}{c}-0.024 \\
{[0.031]}\end{array}$ & $\begin{array}{c}-0.022 \\
{[0.030]}\end{array}$ & $\begin{array}{c}-0.024 \\
{[0.031]}\end{array}$ & $\begin{array}{c}-0.023 \\
{[0.030]}\end{array}$ \\
\hline GDP, $\%$ change & $\begin{array}{l}-0.373 \\
{[0.528]}\end{array}$ & $\begin{array}{l}-0.372 \\
{[0.527]}\end{array}$ & $\begin{array}{l}-0.376 \\
{[0.528]}\end{array}$ & $\begin{array}{c}-0.373 \\
{[0.529]}\end{array}$ \\
\hline Prev. PAN vote & $\begin{array}{l}0.660^{* * *} \\
{[0.048]}\end{array}$ & $\begin{array}{l}0.660^{* * *} \\
{[0.049]}\end{array}$ & $\begin{array}{l}0.661^{* * *} \\
{[0.048]}\end{array}$ & $\begin{array}{l}0.661^{* * *} \\
{[0.049]}\end{array}$ \\
\hline Poverty & $\begin{array}{c}0.092 \\
{[0.066]}\end{array}$ & $\begin{array}{l}0.09 \\
{[0.065]}\end{array}$ & $\begin{array}{c}0.092 \\
{[0.066]}\end{array}$ & $\begin{array}{c}0.091 \\
{[0.065]}\end{array}$ \\
\hline$\%$ Urban & $\begin{array}{l}-0.022 \\
{[0.040]}\end{array}$ & $\begin{array}{c}-0.024 \\
{[0.038]}\end{array}$ & $\begin{array}{l}-0.023 \\
{[0.040]}\end{array}$ & $\begin{array}{c}-0.023 \\
{[0.039]}\end{array}$ \\
\hline Population log. & $\begin{array}{l}-0.525 \\
{[0.378]}\end{array}$ & $\begin{array}{l}-0.542 \\
{[0.376]}\end{array}$ & $\begin{array}{l}-0.522 \\
{[0.377]}\end{array}$ & $\begin{array}{c}-0.531 \\
{[0.377]}\end{array}$ \\
\hline Constant & $\begin{array}{l}12.749 \\
{[8.080]}\end{array}$ & $\begin{array}{l}13.07 \\
{[8.037]}\end{array}$ & $\begin{array}{l}12.739 \\
{[8.078]}\end{array}$ & $\begin{array}{l}12.949 \\
{[8.051]}\end{array}$ \\
\hline $\begin{array}{l}\text { Observations } \\
\text { R-squared }\end{array}$ & $\begin{array}{r}2,411 \\
0.533\end{array}$ & $\begin{array}{r}2,411 \\
0.533\end{array}$ & $\begin{array}{r}2,411 \\
0.534\end{array}$ & $\begin{array}{r}2,411 \\
0.534\end{array}$ \\
\hline
\end{tabular}

Clustered standard errors in brackets.

${ }^{* * *} \mathrm{p}<0.01,{ }^{* *} \mathrm{p}<0.05,{ }^{*} \mathrm{p}<0.10$ 
Table 4. Individual Vote Choice in the 2012 Mexican Presidential Election

\begin{tabular}{|c|c|c|c|c|}
\hline & Model 1 & Model 2 & Model 3 & Model 4 \\
\hline \multicolumn{5}{|l|}{ Fixed Effects } \\
\hline \multicolumn{5}{|l|}{ Level-2 predictors } \\
\hline Intercept & $\begin{array}{c}-3.214^{* * *} \\
{[0.505]}\end{array}$ & $\begin{array}{c}-3.225^{* * *} \\
{[0.509]}\end{array}$ & $\begin{array}{c}-3.243^{* * *} \\
{[0.514]}\end{array}$ & $\begin{array}{c}-3.453^{* * *} \\
{[0.523]}\end{array}$ \\
\hline Homicide rate, CVM & & $\begin{array}{c}-0.002 \\
{[0.009]}\end{array}$ & & $\begin{array}{c}-0.002 \\
{[0.009]}\end{array}$ \\
\hline Homicide rate, INEGI & & & $\begin{array}{c}0.001 \\
{[0.003]}\end{array}$ & \\
\hline Criminal-electoral violence & & $\begin{array}{c}0.084 \\
{[0.242]}\end{array}$ & $\begin{array}{l}0.06 \\
{[0.237]}\end{array}$ & $\begin{array}{c}0.091 \\
{[0.246]}\end{array}$ \\
\hline PAN mayor dummy & & & & $\begin{array}{c}0.920^{* *} \\
{[0.396]}\end{array}$ \\
\hline \multicolumn{5}{|l|}{ Level-1 predictors } \\
\hline Evaluation of national (in)security & $\begin{array}{c}-0.395^{* *} \\
{[0.175]}\end{array}$ & $\begin{array}{c}-0.398^{* *} \\
{[0.175]}\end{array}$ & $\begin{array}{c}-0.396^{* *} \\
{[0.175]}\end{array}$ & $\begin{array}{c}-0.213 \\
{[0.191]}\end{array}$ \\
\hline Evaluation*PAN & & & & $\begin{array}{c}-0.740^{* *} \\
{[0.305]}\end{array}$ \\
\hline Victim & $\begin{array}{c}-0.096 \\
{[0.313]}\end{array}$ & $\begin{array}{c}-0.092 \\
{[0.313]}\end{array}$ & $\begin{array}{c}-0.096 \\
{[0.313]}\end{array}$ & $\begin{array}{c}-0.111 \\
{[0.315]}\end{array}$ \\
\hline Responsibility attribution & $\begin{array}{c}-0.506 \\
{[0.356]}\end{array}$ & $\begin{array}{c}-0.512 \\
{[0.356]}\end{array}$ & $\begin{array}{c}-0.506 \\
{[0.356]}\end{array}$ & $\begin{array}{c}-0.451 \\
{[0.359]}\end{array}$ \\
\hline Evaluation*Attribution & $\begin{array}{c}0.234 \\
{[0.159]}\end{array}$ & $\begin{array}{c}0.238 \\
{[0.159]}\end{array}$ & $\begin{array}{c}0.233 \\
{[0.159]}\end{array}$ & $\begin{array}{c}0.211 \\
{[0.160]}\end{array}$ \\
\hline Evaluation of national economy & $\begin{array}{c}-0.208^{*} \\
{[0.108]}\end{array}$ & $\begin{array}{c}-0.208^{*} \\
{[0.109]}\end{array}$ & $\begin{array}{c}-0.205^{*} \\
{[0.109]}\end{array}$ & $\begin{array}{c}-0.219^{* *} \\
{[0.109]}\end{array}$ \\
\hline Presidential approval & $\begin{array}{l}1.125^{* * *} \\
{[0.189]}\end{array}$ & $\begin{array}{l}1.124^{* * *} \\
{[0.189]}\end{array}$ & $\begin{array}{l}1.124^{* * *} \\
{[0.189]}\end{array}$ & $\begin{array}{l}1.117^{* * *} \\
{[0.190]}\end{array}$ \\
\hline PAN identification & $\begin{array}{l}3.886^{* * *} \\
{[0.191]}\end{array}$ & $\begin{array}{l}3.888^{* * *} \\
{[0.191]}\end{array}$ & $\begin{array}{l}3.888^{* * *} \\
{[0.191]}\end{array}$ & $\begin{array}{l}3.915^{* * *} \\
{[0.193]}\end{array}$ \\
\hline TV consumption & $\begin{array}{c}0.154^{*} \\
{[0.083]}\end{array}$ & $\begin{array}{c}0.155^{*} \\
{[0.083]}\end{array}$ & $\begin{array}{c}0.155^{*} \\
{[0.083]}\end{array}$ & $\begin{array}{c}0.153^{*} \\
{[0.084]}\end{array}$ \\
\hline Education & $\begin{array}{c}0.067 \\
{[0.044]}\end{array}$ & $\begin{array}{c}0.068 \\
{[0.045]}\end{array}$ & $\begin{array}{c}0.067 \\
{[0.044]}\end{array}$ & $\begin{array}{c}0.067 \\
{[0.045]}\end{array}$ \\
\hline Age & $\begin{array}{c}-0.002 \\
{[0.006]}\end{array}$ & $\begin{array}{c}-0.002 \\
{[0.006]}\end{array}$ & $\begin{array}{c}-0.002 \\
{[0.006]}\end{array}$ & $\begin{array}{c}-0.002 \\
{[0.006]}\end{array}$ \\
\hline Female & $\begin{array}{l}0.598^{* * *} \\
{[0.172]}\end{array}$ & $\begin{array}{l}0.597^{* * *} \\
{[0.173]}\end{array}$ & $\begin{array}{l}0.600^{* * *} \\
{[0.172]}\end{array}$ & $\begin{array}{l}0.592^{* * *} \\
{[0.173]}\end{array}$ \\
\hline \multicolumn{5}{|c|}{ Random Effects Variance Components } \\
\hline Municipal level effect (variance) & 0.000 & 0.000 & 0.000 & 0.000 \\
\hline Observations & 1,897 & 1,897 & $1,897 \quad 1$ & 1,897 \\
\hline Number of groups & 108 & 108 & 108 & 108 \\
\hline
\end{tabular}

Standard errors in brackets.

${ }^{* * *} \mathrm{p}<0.01,{ }^{* *} \mathrm{p}<0.05,{ }^{*} \mathrm{p}<0.10$ 
sis. The CSES sample did not include municipalities that experienced events of criminal-electoral violence targeted against PAN members or public officials.

The lack of effect of objective contextual violence on vote choice is puzzling. However, this result is consistent with other studies that have found that presidential approval ratings are not affected by homicides but are influenced by other types of organized crime activity, such as kidnappings (Romero and Magaloni 2013). Unfortunately, official crime statistics in that regard are not reliably disaggregated at the municipal level, and I am unable to test the effects of other types of crimes on vote choice. Also, given that homicide rates are negatively associated with participation (Bravo and Maldonado 2012; Carreras and Trelles 2012; Ley 2014), crime issue voting may be limited. As I have noted elsewhere (Ley 2014), increasing homicide rates have the double effect of reducing support for both democratic institutions and participation. Therefore, if voters exposed to violence do not believe that elections can help improve the situation of insecurity, this implies that the main effects of violence are reflected through abstention rather than the incumbent's vote share. Citizens' disapproval is expressed through nonparticipation rather than electoral punishment.

Still, consistent with $\mathrm{H} 1$, the negative and statistically significant coefficient ( $\mathrm{p}$ $<0.05$ ) for the variable on evaluations of national security (models 1-3) indicates that as individual perceptions of the country's insecurity worsened, the probability of voting for the national incumbent party (PAN) diminished. Holding all other predictors at their median values, a voter who believed that the situation of violence in the country had worsened over the preceding year was 8 percent less likely to vote for the PAN candidate than a voter who thought the situation had improved. ${ }^{17}$

Model 4 tests whether this effect varies according to the partisanship of the voter's municipal incumbent government. Consistent with $\mathrm{H} 2$, the results show that electoral support for the national in-party is conditional on the party identification of lower levels of government. The positive and statistically significant coefficient for the PAN mayor dummy shows that only when the mayor belonged to the president's party did a perceived improvement of national security (Evaluation $=0$ ) translate into a vote for the national incumbent party. The lack of statistical significance for the coefficient of the evaluation of (in)security indicates that when the voter's mayor belonged to a party different from that of the president (PAN mayor $=0$ ), worsening evaluations did not affect the probability of voting for the national incumbent. The interaction term indicates that worsening evaluations of national security had a negative effect on the probability of voting for the incumbent national party only when the mayor belonged to the president's party (PAN mayor $=1$ ).

Figure 1 graphically shows this effect. Among voters living in municipalities ruled by the opposition (non-PAN governments), worsening perceptions of insecurity did not alter the probability of voting for the national incumbent party. However, for people living in municipalities ruled by the PAN, deteriorating perceptions did have a clear negative effect on the probability of voting for the national incumbent party. This result is consistent with the findings at the aggregate level of analysis. The PAN's emphasis on the issue of security, as a way to support the federal gov- 
Figure 1. Marginal Effect of Evaluations of National Security on the

Probability of Vote for the National Incumbent, by Mayor's Party

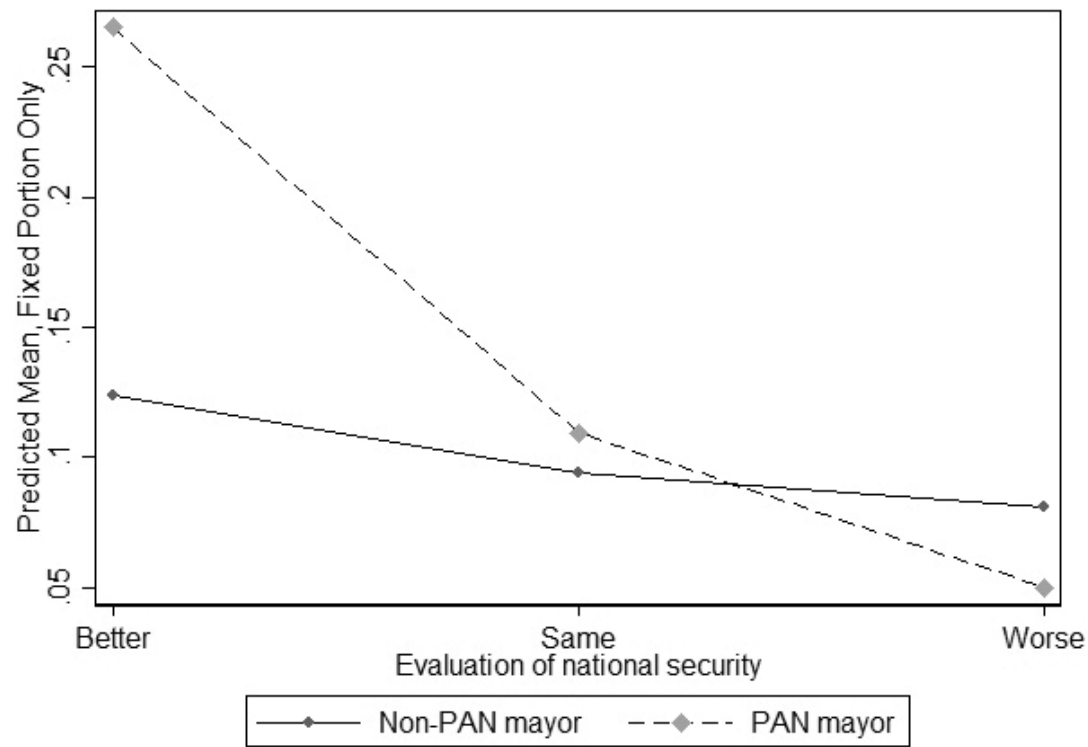

ernment's war on drugs, backfired in PAN-led municipalities when violence did not appear to be under control—at least from the voters' perspective-and when the political discourse attempted to convince voters otherwise.

Table 4 further reveals that being a victim of a crime does not affect the probability of voting for the incumbent party. This is consistent with other works that have found that personal victimization does not affect vote choice (Pérez 2015) or presidential approval (Romero 2013). However, this finding does not mean that the victimization experience has no effect on voting behavior. As noted in other recent studies on the political consequences of criminal violence, victims are also generally less likely to participate in elections (Ley 2014). As mentioned previously, it is possible that victims express their rejection or disapproval of the incumbent party's performance by not participating in the election.

Finally, the measure of direct responsibility attribution did not have an effect on voting preferences. However, news consumption has a significant impact on support for the incumbent government. Individuals who watched more TV news were more likely to support the national incumbent party. As discussed before, even if campaigns ignored the topic of insecurity, the majority of Calderón's public appearances and speeches emphasized his administration's efforts to combat crime. This finding may suggest that, as other works have shown, exposure to crime news may increase support for iron fist policies (Krause 2014). It also reminds us that electoral accountability depends on voters' ability to obtain politically relevant information about their government's performance (Marshall 2015). 


\section{Conclusions}

This study examined the extent to which Mexican elected authorities have been held accountable for rising crime and insecurity across the country. The results indicate that Mexican voters held local governments accountable for rising violence under specific circumstances: when their elected authorities were politically aligned and insecurity was the result of organized criminal activity, particularly when directed against public figures.

For an issue as complex as organized crime, voters rely on cognitive shortcuts through which to attribute blame and consequently to decide whom to vote for. Consistent with previous works on responsibility attribution, this study finds that when upper and lower levels of government share the same partisanship, voters are able to punish or reward the incumbent government according to its performance in the control of crime. Specifically, organized crime activity has been particularly important for Mexican voters.

Overall, the results suggest that when a party attempts to "own" crime but fails to provide security, voters will punish its candidates at the polls, and even more so when political alignment facilitates responsibility attribution for poor security performance. In the Mexican case, by emphasizing their efforts to fight crime in their public appearances and electoral campaigns, Calderón and his copartisans at the subnational level made the issue of insecurity the basis of voters' decisions to support the PAN. Rising violence-particularly that directed against politicians—resulted in diminished electoral support only for PAN local candidates, especially in municipalities governed by that party. As proposed by the responsible party hypothesis, party alignment across levels of government made it easier for voters to attribute responsibility and to punish the national incumbent party accordingly. Also, while contextual measures of crime did not appear to affect vote choice in the 2012 presidential election, individual-level data reveal that perceptions of insecurity did play an important role, although also mediated by political alignment. Voters who considered security to have worsened were less likely to vote for the national incumbent party only when their mayor belonged to that same party.

These findings are particularly important for the Latin American region, where many new democracies are being challenged by organized crime groups. This article shows that under certain circumstances, voters living amid criminal violence may be able to hold their governments accountable for rising insecurity. However, the results for partisan alignment also suggest that the opposition may be able to escape electoral accountability despite its shared responsibility for prevailing violence. Moreover, by politicizing the issue of crime, as the Mexican case suggests, political parties further complicate voters' ability to attribute responsibility without necessarily enhancing security policies or contributing to the reduction of violence. This is an alarming matter because continued insecurity, along with weak accountability mechanisms, can have devastating consequences for democratic development. In the long run, this dangerous combination could open opportunities for organized criminal groups to shape electoral outcomes and democratic politics. 
Given that perceptions of insecurity were found to shape voting behavior deeply, it is also fundamental to understand how such perceptions and feelings of insecurity are formed. While criminologists, sociologists, and psychologists have developed this agenda, the literature has failed to look at its implications in the political domain. The results presented here indicate that perceptions of insecurity need to be examined in the political context in which they are constructed.

\section{Notes}

I am grateful to Karen Remmer, John Aldrich, David Soskice, Chappell Lawson, Melina Altamirano, Francisco Cantú, David Gaddis Smith, and participants at the 2013 American Political Science Association Conference for insightful suggestions. Special thanks to Guillermo Trejo for the collaborative data collection project and his invaluable feedback. The comments and suggestions of three anonymous reviewers also greatly strengthened this paper. The financial support of the Department of Political Science, the Center of Latin American and Caribbean Studies, the Graduate School, and the Trent Foundation at Duke University, as well as the Kellogg Institute for International Studies at the University of Notre Dame, enabled the data collection on violence in Mexico. Thanks to Valeria Ramírez, Mario Moreno, Elizabeth Orozco, and Magdalena Guzmán for superb research assistance, as well as to the Parametría and Buendía y Laredo teams for their work and support. Errors and omissions remain my own. The online appendix may also be found on the author's website: https://sandraley.net

1. Campaign spots are available at Instituto Federal Electoral-Comité de Radio y Televisión. http://pautas.ife.org.mx/transparencia/proceso_2009/index.html.

2. The candidates were Josefina Vázquez Mota (PAN); Enrique Peńa Nieto (Partido de la Revolución Institucional, PRI); Andrés Manuel López Obrador (Partido de la Revolución Democrática, PRD), running in his second consecutive presidential election; and Gabriel Quadri (Nueva Alianza, a relatively smaller and younger party).

3. This was a postelectoral survey with national representation, designed in collaboration with Dr. Cassy Dorff (University of New Mexico) and conducted four days after the July 1, 2012, federal election in Mexico. Buendía y Laredo, one of the main survey firms in Mexico, was in charge of 1,000 face-to-face interviews among Mexican adults 18 years of age or older across the nation. The survey's methodological report and IRB approval are available on request. For the data in table 1, respondents were first asked to evaluate the country's situation of security retrospectively: "Thinking about the last 12 months, would you say that the country's security . . . has improved or worsened?" Next, they were asked a follow up question on responsibility attribution: "And who would you say is responsible for the fact that the country's security [insert answer from previous question (improved, worsened)]?" "All," "None," and "Other" were spontaneous answers by respondents.

4. Mexican mayors remain in power for three years. Therefore, the dataset includes one election cycle per municipality. It excludes municipalities that elect local authorities according to local traditional laws. Mexico's Federal District, which had a special administrative status, is also excluded from the analysis. Mexican mayors during this period could not run for re-election.

5. Based on multiple newspaper sources, the CVM Dataset gathers detailed information on 17,368 organized crime-related events, resulting in 45,161 victims, between 1995 and 2012. It includes the names of the organizations involved, the type of violent actions, the 
identity of victims, and their affiliation by state and municipality. When newspaper reports did not clearly attribute responsibility for a violent event to a specific criminal organization, the authors relied on three indicators to include the event in the dataset: the use and type of assault weapons for killing; signs of torture and brutal violence (e.g., bodies wrapped in a rug or mutilated); and written messages left on the bodies.

6. The homicide rate per one thousand inhabitants is used because the demographic density at the municipal level is significantly lower than national aggregates. See Carreras and Trelles 2012.

7. Data obtained from INEGI's Banco de Información Económica.

8. The main results hold if I average the incumbent party's vote over the previous three elections.

9. It followed a stratified sampling in 234 electoral sections. The country was divided into four strata: states governed by the PAN, northern states governed by the PRI, southern states governed by the PRI, and states governed by the PRD. Each stratum was then divided into strata of political competition according to the 2009 results. Within each stratum, electoral sections were selected in a systematic sampling with probability proportional to the size of each section (PPS). For more details, visit http://biiacs-dspace.cide.edu (BIIACS 2012).

10. See table $\mathrm{C}$ in the appendix for wording and coding of survey questions.

11. Since the sample did not include the smallest municipalities, this analysis used the homicide rate per one hundred thousand people.

12. Table $\mathrm{A}$ in the appendix shows that using the percent change in the homicide rate yields the same results. Just like the standard measure of the lagged homicide rate, the change in the homicide rate does not have an effect on either dependent variable.

13. Out of the 1,993 municipalities included in the analysis, 96 municipalities experienced at least one event of criminal-electoral violence during the campaign season. This represents 4 percent of the total of Mexican municipalities under study.

14. As in the previous analysis, table $\mathrm{B}$ in the appendix shows that using the percent change in the homicide rate yields the same results.

15. The 95 percent confidence intervals for this variable in model 3 are: $[-6.653$, 0.049]. And for model 4: [-6.597, 0.042]. This suggests plausible effects despite the $p<0.10$ level of significance.

16. Estimations show zero variance at the municipal level. However, according to Chung et al. (2013), a zero likelihood ratio test statistic should not necessarily lead us to accept the null hypothesis and proceed as if the true variance were zero.

17. The median values would represent a 41-year-old woman who completed secondary school, was not a victim of crime, attributed responsibility for security to the federal government, considered the economy to be the same as the year before, approved of the president but did not identify with the PAN, and watched a few TV news programs.

To predict the probability of voting, I averaged over simulated values of $\mathrm{u}_{0 \mathrm{j}}$ drawn from a normal distribution with variance equal to the estimated level 2 variance; that is, $\mathrm{N}\left(0, \sigma_{\mathrm{u}}{ }_{\mathrm{u}}\right)$. The predicted probabilities presented here are based only on the fixed part of the model. The random part of the model is ignored, making this equivalent to setting $u_{j}=0$. 


\section{REFERENCES}

Altheide, David L. 2002. Creating Fear: News and the Construction of Crisis. New York: Aldine de Gruyter.

Álvarez, Juan. 2010. Llamado a Calderón. Milenio Tamaulipas (Tampico), Nacional, June 30, 9.

Andreas, Peter, and Joel Wallman. 2009. Illicit Markets and Violence: What Is the Relationship? Crime, Law and Social Change 52, 3: 225-29.

Arceneaux, Kevin. 2003. The Conditional Impact of Blame Attribution on the Relationship Between Economic Adversity and Turnout. Political Research Quarterly 56, 1: 67-75.

Arias, Enrique Desmond. 2006. The Dynamics of Criminal Governance: Networks of Social Order in Rio de Janeiro. Journal of Latin American Studies 38, 2: 293-325.

Azuara, Patricia. 2010. Generación de empleos. Milenio Tamaulipas (Tampico), Nacional, June 22, 6.

Banco de Información para la Investigación Aplicada en Ciencias Sociales (BIIACS). 2012. Mexican Comparative Study of Electoral Systems (CSES). Mexico City: Centro de Investigación y Docencia Económicas. http://biiacs-dspace.cide.edu.

Bateson, Regina. 2012. Crime Victimization and Political Participation. American Political Science Review 106, 3: 570-87.

Beckett, Katherine. 1997. Making Crime Pay: Law and Order in Contemporary American Politics. Oxford: Oxford University Press.

Beltrán, José Alfredo. 2010. Vizcarra “olvidó” seguridad, dice Ortiz. Noroeste (Culiacán), June 4.

Berinsky, Adam. 2005. The Perverse Consequence of Electoral Reform in the United States. American Politics Research 33, 4: 471-91.

Bravo, Carlos, and Gerardo Maldonado. 2012. Balas y votos: ¿Qué efecto tiene la violencia sobre las elecciones? In Las bases sociales del crimen organizado y la violencia en México, ed. José Antonio Aguilar. Mexico City: Secretaría de Seguridad Pública. 309-36.

Bravo Regidor, Carlos. 2011. Una ayudadita de memoria para Felipe Calderón. Nexos, Blog de la redacción, January 28. http://redaccion.nexos.com.mx/?p=2571.

Canes-Wrone, Brandice, William Minozzi, and Jessica Bonney Reveley. 2011. Issue Accountability and the Mass Public. Legislative Studies Quarterly 36, 1: 5-35.

Carreras, Miguel, and Alejandro Trelles. 2012. Bullets and Votes: Violence and Electoral Participation in Mexico. Journal of Politics in Latin America 4, 2: 89-123.

Caudillo, Monica L., and Florencia Torche. 2014. Exposure to Local Homicides and Early Educational Achievement in Mexico. Sociology of Education 87, 2: 89-105.

Chin, Ko-lin, and Roy Godson. 2006. Organized Crime and the Political-Criminal Nexus in China. Trends in Organized Crime 9, 3: 5-44.

Chung, Yeojin, Sophia Rabe-Hesketh, Vincent Dorie, Andrew Gelman, and Jingchen Liu. 2013. A Nondegenerate Penalized Likelihood Estimator for Variance Parameters in Multilevel Models. Psychometrika 284: 1-25.

Cummins, Jeff. 2009. Issue Voting and Crime in Gubernatorial Elections. Social Science Quarterly 90, 3: 632-51.

Data Cívica. 2015. Desaparecidos. http://datacivica.org/2015/04/21/desaparecidos

Durán-Martínez, Angélica. 2015. To Kill and Tell? State Power, Criminal Competition, and Drug Violence. Journal of Conflict Resolution 59, 8: 1377-1402.

Felbab-Brown, Vanda. 2010. Shooting Up: Counterinsurgency and the War on Drugs. Washington, DC: Brookings Institution Press. 
García, Adán. 2011. Acusan uso político de asesinato de Edil. Reforma (Mexico City), Nacional, November 3.

García, Lev. 2011. Promete "Cocoa” erradicar extorsión. Reforma, Estados, September 4.

Gélineau, François, and Karen Remmer. 2006. Political Decentralization and Electoral Accountability: The Argentine Experience, 1983-2001. British Journal of Political Science 36, 1: 133-57.

Hagan, Frank E. 1983. Organized Crime Continuum: A Further Specification of a New Conceptual Model. Criminal Justice Review 8: 52-57.

Hernández, Erika, and Claudia Salazar. 2010. Enfrenta seguridad a PRI y AN. Reforma (Mexico City), Nacional, September 6, 6.

Hobolt, Sara, James Tilley, and Susan Banducci. 2013. Clarity of Responsibility: How Government Cohesion Conditions Performance Voting. European Journal of Political Research 52, 2: 164-87.

Holmes, Jennifer S., and Sheila Amin Gutiérrez de Piñeres. 2012. Security and Economic Voting: Support for Incumbent Parties in Colombian Presidential Elections. Democratization 20, 6: 1117-43.

Javeline, Debra. 2003. Protest and the Politics of Blame: The Russian Response to Unpaid Wages. Ann Arbor: University of Michigan Press.

Krause, Krystin. 2014. Supporting the Iron Fist: Crime News, Public Opinion, and Authoritarian Crime Control in Guatemala. Latin American Politics and Society 56, 1 (Spring): 98-119.

Langston, Joy and Sandra Ley. 2016. The Elephant in the Room: When Do Congressional Candidates Mention Security Issues? Working Paper. Political Studies Division, CIDE.

Ley, Sandra. 2014. Citizens in Fear: Political Participation and Voting Behavior in the Midst of Violence. Ph.D. diss., Duke University.

Ley, Sandra, and Cassy Dorff. 2012. Survey of responsibility attribution for the security situation in Mexico. Conducted July 5-8.

Leyden, Kevin M., and Stephen A. Borrelli. 1995. The Effect of State Economic Conditions on Gubernatorial Elections: Does Unified Government Make a Difference? Political Research Quarterly 48, 2: 275-90.

Luján, Francisco. 2011. Ataque a Leyzaola rompe relación municipio-federación. Norte de Ciudad Juárez, July 27.

Marion, Nancy E., and Rick Farmer. 2003. Crime Control in the 2000 Presidential Election. American Journal of Criminal Justice 27, 2: 129-44.

Marshall, John. 2015. Political Information Cycles: When Do Voters Sanction Incumbent Parties for High Homicide Rates? Working paper. Department of Political Science, Harvard University.

Minjares, Gabriela. 2010. Se suma Creel a guerra de acusaciones contra Duarte. El Diario de Chihuahua (Chihuahua City), June 26, 11.

Molzahn, Cory, Octavio Rodríguez Ferreira, and David A. Shirk. 2013. Drug Violence in Mexico: Data and Analysis Through 2012. San Diego: Trans Border Institute, Joan B. Kroc School of Peace Studies, University of San Diego.

Nacif, Benito. 2002. Understanding Party Discipline in the Mexican Chamber of Deputies: The Centralized Party Model. In Legislative Politics in Latin America, ed. Scott Morgenstern and Nacif. Cambridge: Cambridge University Press. 254-86.

Norpoth, Helmut. 2001. Divided Government and Economic Voting. Journal of Politics 63, 2: 414-35. 
Norzagaray López, Miguel David. 2010. El narcotráfico en México desde el discurso oficial. Ph.D. thesis, Facultad Latinoamericana de Ciencias Sociales, Mexico City.

Pérez, Orlando J. 2015. The Impact of Crime on Voter Choice in Latin America. In The Latin American Voter: Pursuing Representation and Accountability in Challenging Contexts, ed. Ryan E. Carlin, Matthew M. Singer, and Elizabeth J. Zechmeister. Ann Arbor: University of Michigan Press. 324-45.

Powell, G. Bingham, and Guy D. Whitten. 1993. A Cross-National Analysis of Economic Voting: Taking Account of the Political Context. American Journal of Political Science 37, 2: 391-414.

Prillaman, William C. 2003. Crime, Democracy, and Development in Latin America. Policy Papers on the Americas 14, 6:1-30. Washington, DC: Center for Strategic and International Studies.

Putnam, Kate. 2013. Campaigns, Issue Voting, and Crime in Developing Democracies: Evidence from Mexico's Recent Elections. Paper presented at the Annual Meeting of the Midwest Political Science Association, Chicago, April 11-14.

Reforma (Mexico City). 2009. Debaten de crimen y exigen acciones. Nacional, May 28, 4.

Robles, Gustavo, Beatriz Magaloni, and Gabriela Calderón. 2013. The Economic Costs of Drug-Trafficking Violence in Mexico. Working paper. Stanford: Program on Poverty and Governance, Stanford University.

Romer, Daniel, Kathleen Hall Jamieson, and Sean Aday. 2003. Television News and the Cultivation of Fear of Crime. Journal of Communication 53, 1: 88-104.

Romero, Oscar. 2010. El crimen, respuesta de la delincuencia: Peńa Nieto. Milenio Tamaulipas (Tampico), Nacional, June 29, 9.

Romero, Vidal. 2013. Impacto de los temas de seguridad pública en la aprobación presidencial. Politica y Gobierno, Thematic Volume: 117-38.

Romero, Vidal, and Beatriz Magaloni. 2013. How Do Crime and Violence Impact Presidential Approval? Examining the Dynamics of the Mexican Case. Paper prepared for presentation at the 2013 American Political Science Association Annual Meeting, Chicago, August 29-September 1.

Rudolph, Thomas J. 2003. Who's Responsible for the Economy? The Formation and Consequences of Responsibility Attributions. American Journal of Political Science 47, 4: 698-713.

Sabet, Daniel. 2012. Police Reform in Mexico: Informal Politics and the Challenge of Institutional Change. Stanford: Stanford University Press.

Sampson, Robert. 1985. Neighborhood and Crime: The Structural Determinants of Personal Victimization. Journal of Research in Crime and Delinquency 22, 1: 7-40.

Sberna, Salvatore. 2011. Electoral Competition and Criminal Violence in Italy (1983-2003). Paper presented at the European Consortium for Political Research Joint Session Conference Workshop on Political Institutions and Conflict, St. Gallen, Switzerland, April $12-17$.

Simon, Jonathan. 2006. Governing Through Crime: How the War on Crime Transformed American Democracy and Created a Culture of Fear. Oxford: Oxford University Press.

Singer, Matthew M. 2011. Who Says "It's the Economy"? Cross-National and Cross-Individual Variation in the Salience of Economic Performance. Comparative Political Studies 44, 3: 284-312.

Smith, Jason M. 2010. Does Crime Pay? Issue Ownership, Political Opportunity, and the Populist Right in Western Europe. Comparative Political Studies 43, 1: 1471-98. 
Snyder, Richard, and Angélica Durán-Martínez. 2009. Does Illegality Breed Violence? Drug Trafficking and State-Sponsored Protection Rackets. Crime, Law, and Social Change 52, 3: 253-73.

Trejo, Guillermo, and Sandra Ley. 2015. Municipios bajo fuego (1995-2014). Nexos, February 1. http://www.nexos.com.mx/?p=24024.

- 2016. Federalism, Drugs, and Violence: Why Intergovernmental Partisan Conflict Stimulated Inter-Cartel Violence in Mexico. Politica y Gobierno 23, 1: 9-52.

Uang, Randy Sunwin. 2013. Campaigning on Public Security in Latin America: Obstacles to Success. Latin American Politics and Society 55, 2 (Summer)): 26-51.

Varese, Federico, ed. 2010. Introduction: What Is Organized Crime? In Organized Crime: Critical Concepts in Criminology, ed. Varese. London: Routledge. 1-33.

Villarreal, Andrés, and Braulio F. Silva. 2006. Social Cohesion, Criminal Victimization, and Perceived Risk of Crime in Brazilian Neighborhoods. Social Forces 84, 3: 1725-53.

\section{SUPPORTING INFORMATION}

Additional supporting materials may be found with the online version of this article at the publisher's website:

1. Appendix: Additional Models and Survey Questions 